\title{
Analysis of landscape performance assessment by key stakeholders in a transfrontier conservation area
}

\author{
"MUNYARADZI CHITAKIRA1', EMMANUEL TORQUEBIAU'2, WILLEM FERGUSON \\ \& KEVIN MEARNS ${ }^{1}$
}

${ }^{1}$ UNISA, Department of Environmental Sciences, South Africa.

${ }^{2}$ CIRAD, UR 105, F-34398, Montpellier, France.

${ }^{3}$ University of Pretoria, Centre for Environmental Studies / Department of Zoology and Entomology, South Africa.

*Corresponding author

ABSTRACT Stakeholder engagement has become an important aspect of sustainable natural resources management. This study analysed a landscape performance assessment by local and 'external' stakeholders in a transfrontier conservation area in Southern Africa. The landscape was divided into three agro-ecological zones and focus group discussions were facilitated for stakeholders to evaluate the landscape based on four ecoagriculture dimensions (production, conservation, livelihoods and institutions). The conservation dimension showed the best performance and the overall score for the landscape was 2.97, implying a fairly good performance. Perceptions and ratings did not significantly differ by age, gender or stakeholder groups. We conclude that despite their low levels of formal education and training, communal farmers can assess the performance of local landscapes in a consistent way. This study provides information about the degree to which the landscape under focus conformed to the main ecoagriculture goals and can guide development planning and extension service provision. 
Key Words: Multifunctional landscapes, landscape performance, ecoagriculture, TFCAs, stakeholders, participatory.

\section{Introduction}

The evaluation of rural landscapes is often performed by professional research teams or consultants using sophisticated techniques while local communities are passively involved, which is a kind of top-down as opposed to bottom-up or participatory approach (Bastin, et al., 2002; Butler et al., 2015; Li et al., 2014; Reed et al., 2013; Taner, et al., 2014; Xu et al., 2014). Research has revealed that the attitudes, intention to use and actual usage of a new technology by targeted beneficiaries depends on several factors which include the perception of user friendliness and ease of learning the technology (Lee \& Coughlin, 2015). This observation underscores the importance of adopting simpler approaches in rural development. In the present study, key stakeholders evaluated the performance of the local landscape using a relatively simple checklist which lowly educated stakeholders can adopt. The landscape was evaluated on four performance areas or dimensions, namely: agricultural production, biodiversity conservation, livelihoods improvement and institutional coordination. These dimensions form the main goals of ecoagriculture (Buck et al., 2006; Scherr et al., 2014) and in this study they serve as indicators for the state of biodiversity-agriculture integration in the area under investigation. Indicators are useful for assessing the state of natural resource systems, comparing different localities and monitoring changes over time (Sayer et al., 2007). Land uses that promote biodiversity-agriculture integration with benefits to local communities are known to enhance the sustainability of agricultural landscapes (FAO, 2012a; Jackson et al., 2007). 
This study focused on a border community in a transfrontier conservation area (TFCA) in Southern Africa and provides insights into effective stakeholder engagement in landscape management. Since the 1990s, the TFCAs model has gained popularity in Southern Africa (Duffy, 2005; Shames \& Scherr, 2009). Theoretically, TFCAs are multifunctional landscapes intended to provide substantial environmental benefits including improved biodiversity conservation, socio-economic development and sustainable livelihoods (SADC, 2012). However, it is not clear to what extent the TFCA landscapes in Southern Africa are fulfilling the expected benefits and the present study is a contribution towards bridging this gap in information.

\section{Conceptual framework}

Environmental issues are complex, uncertain and multi-scale in nature such that they affect diverse actors and agencies (Reeds, 2008). As such, stakeholder engagement in environmental management has steadily become important at both local and international scales and in some instances, is considered a democratic right (Reed et al., 2013; Voinov et al., 2016). Stakeholder engagement has both benefits and challenges and these are welldocumented in literature (Reed, 2008; Jeffery, 2009; Voinov et al., 2016). Stakeholders can be categorised into local (with detailed information and opinions on a specific issue or region) and global (which engage directly with companies at pan-regional headquarters level) (Jeffery, 2009). It is almost impossible to provide a single definition of "stakeholder" that fits all possible situations (Hörisch et al., 2014). However, a stakeholder is generally defined as anyone who affects or is affected by an organisation; or groups or persons who have a stake, a claim, or an interest in the operations and decisions of an organisation (Freeman, 2010; Jeffery, 2009). In this study, the term stakeholder refers to any individual, group or 
organisation with an interest in multifunctional landscapes or environmental management aspects such as biodiversity, agriculture, natural resources and local livelihoods. Two groups of stakeholders considered in this study are communal farmers (local stakeholders) and professionals and administrators (loosely termed 'external' stakeholders).

A landscape is a cluster of local natural ecosystems and agro-ecosystems characterised by a particular configuration of topography, vegetation, land use and settlement (Brussaard et al., 2010; Farina, 2006; Scherr et al., 2011). The concept includes the biophysical features of an area as well as its institutional and socio-cultural functions. The capacity of a landscape to provide goods and services (e.g. agricultural production, biodiversity protection, aesthetics and cultural uses) known as landscape function, can be maintained through sustainable management practices. Multifunctional landscapes attract different stakeholders by simultaneously providing diverse functions and services. However, they may also generate conflict among the stakeholders if the functions are incompatible (Stockdale \& Barker, 2009; Willemen, 2010). Multifunctional landscapes are therefore likely to experience governance challenges which might affect their performance. The present study expected to reveal any governance challenges which could be affecting the performance of the landscape under focus.

Landscape performance is defined as the degree of effectiveness with which the functions provided by different dimensions or components of a landscape achieve the expected goals and contribute to sustainability (Buck et al., 2006; Landscape Architecture Foundation, 2017). Examples of landscape functions and benefits include atmospheric carbon reduction and the provision of energy, clean water, food, recreational space and habitat for species (Yang et al., 2013; Krováková et al., 2014). In this study, landscape performance assessment (LPA) refers to a process of evaluating a landscape's capability to provide ecosystem goods and services to society and of monitoring the balance between the 
landscape's functions. The assessment of landscape performance can help to find out to what extent the dimensions of a landscape are fulfilling the expectations of the stakeholders and the LPA results can guide intervention measures (Ecoagriculture Partners, 2007; Xu et al., 2014). As such, the LPA process plays an important role in sustainable landscape management.

Assessment of landscape performance assumes a broad perspective as it includes the social, economic, institutional and biophysical dimensions of a landscape (Buck et al., 2006). This broad perspective coupled with factors such as conflicting stakeholder interests and a high degree of context specificity make LPA a complex process. This complexity has prompted research designs that use a combination of quantitative landscape studies such as national storm water calculator and green infrastructure values (Xu et al., 2014). However, uneducated or illiterate people may not be able to utilise such methods which require certain levels of formal training and expertise. The present study adopts a participatory approach to landscape performance assessment (Ecoagriculture Partners, 2012; Willemen et al., 2014) and engages the local communities' and other key stakeholders' perceptions of the sufficiency of local resources and their effectiveness in promoting livelihoods. Research has shown that participation results in greater adoption and use of proposed technologies (Demeke, 2003; Tarawali et al., 2002). As such, participatory approaches are widely used by conservation proponents. However, participatory approaches may meet resistance from stakeholders if the goals are not legitimate or are poorly communicated (Sayer et al., 2007).

For sustainability reasons, LPA in a TFCA needs to engage the local communities who depend on natural resources for their livelihoods (Reed et al., 2013; Voinov et al., 2016). The value of local community involvement in landscape planning has been gaining recognition as the top-down approach to rural development has faced increasing criticism (Aref, 2011; Moseley, 2003; Vallance, 2011). Local stakeholder buy-in and support for 
development and conservation projects is necessary for the achievement of TFCA goals (Duffy, 2005). Recognition of local identity and effective participation in decision making are essential to secure such support (Metcalfe, 2003). The involvement of local communities in planning resource utilisation is expected to promote sustainability through minimising conflict and maximising equitable benefit sharing (Evans et al., 2006). There are, however, challenges associated with local community engagement in landscape assessment. For instance, Sayer et al. (2007) experienced difficulty in selecting stakeholders to engage in discussions of phenomena that were manifest at the landscape scale because most local people and officials found it more natural to discuss issues relating to the smaller units of the landscape for which they were responsible or upon which they were dependent.

One broad framework that gives local farmers the opportunity to monitor landscape performance and take intervention measures is ecoagriculture. Ecoagriculture is the simultaneous development of sustainable food production systems, biodiversity conservation, ecosystem services enhancement and alleviation of poverty in rural communities (Scherr \& McNeely, 2007). This framework observes the principles of devolution and empowerment of local communities (Gruber, 2010). It integrates a diversity of agricultural systems and wider land use mosaics (e.g. forests or human settlements). As such, ecoagriculture can reduce the governance challenges of multifunctional landscapes (Buck et al., 2006).

The study area under focus is made up of integrated patches of unplanned ecoagriculture including traditional spontaneous tree-crop combinations, grass strip contours and hedgerows (Chitakira et al., 2015). The local Jozini municipality is the most populated municipal area within the Umkhanyakude District of KwaZulu-Natal Province in South Africa (Jozini Local Municipality, 2013). In the wake of the above observations the present study sought to assess key stakeholders' perceptions of local landscape performance. This 
information is anticipated to provide insight into stakeholder expectations, inform policy development and advise the management of the TFCA landscape.

\section{Study Objectives}

The study aimed to assess the outcome of landscape performance assessment by key stakeholders in a TFCA. The main research questions were: "what are the key stakeholders' perceptions of a local landscape's performance?" and, "how do the perceptions of key stakeholder groups differ?" The specific objectives were to:

i. Analyse the outcome of landscape performance rating by key stakeholders in the Usuthu-Tembe-Futi TFCA.

ii. Compare the perceptions of local communal farmers and those of professionals and administrators.

iii. Assess the local communal farmers' attitude to ecoagriculture implementation.

iv. Discuss the practical contributions of the study findings.

\section{Materials and Methods}

\subsection{Description of the Study Area}

The study was conducted in a smallholder farming community called the Mathenjwa Tribal Authority (MTA) in Umkhanyakude District in northern KwaZulu-Natal Province of South Africa. This $547 \mathrm{~km}^{2}$ area lies within the Usuthu-Tembe-Futi TFCA straddling the boundaries of South Africa, Mozambique and Swaziland (Figure 1). The MTA comprises landscapes utilised for agriculture or natural resources extraction, as well as protected areas, namely, the Ndumo Game Reserve and the Usuthu Gorge Community Conservation Area (UGCCA). The area is a globally recognised biodiversity hotspot and harbours many endemic plants and endangered vegetation types classified under the subtropical savanna 
biome (Mucina \& Rutherford, 2006; Van Wyk \& Smith, 2001). The climate is dry and warm to hot for most of the year, with an annual rainfall between $500 \mathrm{~mm}$ in the eastern lowlands (about 50m a.s.1.) and $800 \mathrm{~mm}$ in the western uplands (about $600 \mathrm{~m}$ a.s.1.). The communities in the Jozini Local Municipality under which the MTA falls have had limited access to social development services. For instance, $23 \%$ of the households had no access to any form of sanitation facility, $64 \%$ relied on wood energy for cooking, $35 \%$ and $95 \%$ had no access to water and electricity respectively and 49\% had "no income at all" (Jozini Local Municipality 2013:9; 2015:70,72). The inhabitants of this area have been depending mainly on natural resources as their primary means of livelihood (Sotho et al., 2001) which could be a future threat to the local biodiversity.

The study area was divided into three agro-ecological zones based on the elevation above sea level:

i. lower zone (low-lying gently sloping plain, about 50m - 250m a.s.1.),

ii. middle zone (rugged and mountainous transitional area between lower and upper zones, about $250 \mathrm{~m}-450 \mathrm{~m}$ a.s.1.) and

iii. upper zone (dissected plateau, about $450 \mathrm{~m}-600 \mathrm{~m}$ a.s.1.).

The zoning was intended to reveal possible spatial differences in landscape performance. According to the records obtained from the local Traditional Chief's Council (personal communication) there were 3941 households in the area of which $30 \%$ were in the lower zone, $10 \%$ in the middle zone and $60 \%$ in the upper zone.

\subsection{Landscape Performance Rating Meetings}


Three farmers' meetings were facilitated, one meeting in each agro-ecological zone to evaluate the performance of the local landscape with respect to ecoagriculture. Invitations to participate were extended during community meetings coordinated by the headmen of respective villages. After budgetary and other considerations 20 participants were invited to each meeting on a first-to-volunteer basis. The composition of participants was controlled in order to be fairly representative of the community with respect to location (village), gender and age groups. Each meeting was organised into focus groups of about five participants, based on gender and age, recognising that age and gender have been found to have an effect on perception (MaÔano et al., 2004; Mensah et al., 2017). The groups in this study included the "youths" (females and males aged 18-35), "women" (females over 35 years) and "men" (males over 35 years). The actual number of participants depended on the number of invitees who turned up for each meeting.

A fourth meeting was facilitated for multiple-stakeholders (or 'external' stakeholders) comprising administrators and professionals operating in the TFCA. Twenty-seven key stakeholder organisations identified in a preceding study (Chitakira et al., 2012a) were invited to participate in the LPA meeting. A total of 14 participants turned up for the meeting. The meeting was organised into three focus groups (A, B, and C) based on field of expertise. There were between 4 and 6 participants per group. Group A consisted of practitioners in education, rural development, local government, religious and health sectors. In group B were practitioners in biodiversity conservation, environmental management and agricultural extension. Group C comprised local business entrepreneurs, practitioners in the tourism industry and representatives of the local UGCCA committee.

A landscape performance scorecard (LPS) adopted from Buck et al. (2006) with modifications of the range of scores was used in the evaluation process. The LPS was translated into the local language (isiZulu) to ensure effective engagement of the participants 
not conversant with English. The LPS comprises 20 questions that are divided into four categories. Each category of five questions represents one of the four ecoagriculture goals or dimensions which include production, conservation, institutions and livelihoods. The participants in each meeting evaluated the local landscape in their respective groups and agreed on a common rating for each dimension. The participants also discussed possible reasons for the observed performance. The performance rating was based on a five-point scale ranging from 1 to 5 corresponding to "very poor", "poor", "fair", "good" and "very good" performance, respectively. Scores for each section were averaged across all the groups and all zones to obtain the overall score for each ecoagriculture dimension. The scores for the four dimensions were averaged to get the rating for the entire landscape.

\subsection{Questionnaire and Interview Surveys}

A questionnaire (incorporating close-ended and open-ended items) was designed to solicit information from local farmers' household heads (or their representatives) about their willingness to adopt agriculture-biodiversity integration strategies and to establish their levels of education. The sampling procedure involved randomly picking the first household at the edge of the community and thereafter selecting every $6^{\text {th }}$ household. If no respondent was found on the $6^{\text {th }}$ household, then the next household with a potential respondent would be selected. The questionnaire was administered through a face-to-face interview process and the researchers recorded the responses in the questionnaire. Through this method, 170 respondents were interviewed over the three agro-ecological zones and 170 questionnaires completed (100\% response rate). This sample made up $4.3 \%$ of the households in the MTA. Local agricultural extension workers and environmental officers were interviewed as key informants. 


\subsection{Data Capturing and Analysis}

Scores from each stakeholder group were captured and analysed using Microsoft Excel 2010, $\mathrm{R}$ (version 3.1.0) and IBM SPSS Statistics (version 23) programmes, to generate descriptive statistics, graphical presentations and statistical tests. In all tests the significance level was kept at 0.05 .

\section{Results}

The mean scores (or mean ratings) for the landscape's performance in the conservation and institutions dimensions were 3.44 and 3.23 respectively, that is, in the top half of the range (from 1 to 5). The ratings for the livelihoods and production dimensions were generally below the middle of the range (Figure 2). The lowest score was 1.2 (livelihoods dimension) while the highest was 4.6 (conservation dimension). A Kruskal-Wallis rank sum test indicated existence of significant differences among the scores $(p=0.001)$. Multiple comparisons after Kruskal-Wallis revealed that the ratings for the conservation dimension were significantly different from the production and the livelihoods dimensions.

Figure 3 presents the ratings for each dimension per agroecological zone. The mean ratings for the lower zone, upper zone and the middle zone were 3.24, 3.16 and 2.78 respectively. No significant differences were revealed among the ratings for each dimension across the zones (Kruskal-Wallis rank sum test, chi-squared $=2.02, \mathrm{df}=2, p=0.36$ ) or among the average ratings for each zone (Kruskal-Wallis rank sum test, chi-squared $=2, \mathrm{df}=$ $2, p=0.37)$. The landscape was performing generally well across the three different zones. 
Ratings were also analysed on the basis of age groups and gender of the participants. The scores awarded to each dimension of the landscape by the different social groups (youths, men and women) are shown in Figure 4. No significant differences were revealed (Kruskal-Wallis rank sum test, chi-squared $=0, \mathrm{df}=2, p=1.00$ ). However, a general trend was observed. The conservation and institutions dimensions were awarded relatively higher scores by each of the social groups while the production and livelihoods dimensions were awarded relatively low scores.

Apart from local farmers, the perceptions of external or multiple stakeholders (professionals and administrators) were also analysed and are presented in Figure 5. Based on the evaluation by these groups the overall (average) performance score for the MTA landscape was 2.58. The highest score awarded was 3.67 (conservation dimension) and the lowest was 1.80 (livelihoods dimension). There were no significant differences revealed among the ratings by the multiple-stakeholder groups (Kruskal-Wallis chi-squared $=0.0343$, $\mathrm{df}=2, \mathrm{p}=0.983)$. However, the ratings per landscape dimensions were significantly different (Kruskal-Wallis chi-squared $=16.1136, \mathrm{df}=3, p<0.01$ ). The differences were between the conservation and livelihoods dimensions and between the conservation and production dimensions.

A comparison of the perceptions of external and local stakeholders was of interest in this study (Figure 6). Based on the perceptions of the local farmers the overall performance score of the MTA landscape was 3.07 while the external stakeholders placed it at 2.58. It can be observed that numerically the scores by the local farmers were higher than those by external stakeholders. The ranking of means showed that the ratings by professionals and administrators had a lower mean than the ratings by the farmers' groups. However, the overall test does not show significant differences among all the groups $(p=0.12)$. After averaging the ratings by all participating groups the overall performance score for the entire 
MTA landscape came to 2.97. This score falls in the middle of the range which implies fair to good performance.

By means of a questionnaire survey this study also investigated the local farmers' willingness to implement biodiversity-agriculture integrating strategies (Table 1). Most respondents $(92.3 \%)$ were willing to plan and manage multifunctional landscapes in which environmental conservation is highly prioritised like agricultural production. The options cited most were "learning how to manage ecoagriculture landscapes" (97.1\%) and "teaming up with other community members for ecoagriculture planning" (94.7\%). The reason often given for the willingness to integrate farming and biodiversity conservation (in the local Zulu language) was, “Kubalulekile kimi ukugcina imvelo; impilo yethu inake kwimvelo" which means, "It is important for me to conserve the natural environment; our lives depend on the environment." The questionnaire survey also revealed generally low levels of education in the community (Table 2). Almost a third (29.4\%) of the respondents had never been to a formal school and two thirds (58.2\%) had not gone beyond primary school level.

\section{Discussion}

The conservation goal is about the maintenance of biodiversity and ecosystem services (Scherr et al., 2014). Relatively high ratings on this goal indicate the effectiveness of ongoing conservation and awareness programmes in this TFCA, by various conservation agents such as the Ezemvelo KwaZulu-Natal Wildlife, the Wildlands Conservation Trust and the Department of Environmental Affairs. Key informant interviews in the present study revealed that the enactment and enforcement of the National Veld and Forest Fire Act of 1998 (Government of South Africa, 1998) led to a significant reduction in the use of fire as an agent for clearing land for cultivation resulting in increases in flora and fauna diversity in the 
area. These findings confirm the findings by Torquebiau et al. (2012) that since 1942 the MTA landscape has been experiencing an increase in woody cover.

The institutional dimension which was awarded the second highest rating concerns the establishment and maintenance of institutions to spearhead integrated planning, implementation, resource mobilisation and capacity building in support of ecoagriculture (Scherr et al., 2014). If the interests of stakeholder institutions conflict, stakeholder collaboration may be hampered (Bellefontaine et al., 2002). A well-coordinated institutional set-up is important for successful knowledge dissemination, skills development and ecoagriculture planning. The roles and interests of key stakeholders (e.g. traditional authorities, provincial government officials and conservation agents) in the MTA were complementary and generally aimed at conserving biodiversity and improving local livelihoods (Chitakira, 2013). This observation helps to explain the fairly good performance rating (3.2) awarded to the institutions dimension.

The production dimension concerns providing for sustainable and ecologically compatible agricultural production systems (Scherr et al., 2014). Direct observations in this study revealed that the production systems in the MTA were predominantly traditional and tended to support a mutual interdependence of agricultural and natural ecological systems (Figure 7). A relatively low score for the production dimension could be an indication of existing factors limiting agricultural production. Shortage of water for livestock and irrigation was a critical limiting factor (Chitakira et al., 2012b). Lack of support for the farmers inhibited agricultural production. The farmers needed empowerment through better access to indigenous varieties of seeds, draft power, agricultural markets and extension services. Research has shown that local seed varieties are more advantageous to the farmer and the ecosystem than non-native ecotypes (Benkhoua et al., 2017; Kendle \& Rose, 2000). Therefore, effort should focus on provision of indigenous seed varieties. The study 
established that due to recurrent droughts and deteriorating soil conditions crop production had become an unreliable source of livelihood for the farmers.

The livelihoods goal relates to the enhancement of livelihoods and well-being of all the social groups in the landscape (Scherr et al., 2014). A relatively low rating awarded to this goal is a reflection of high levels of poverty, food shortages, poor housing conditions, as well as limited access to clean water and healthcare (Cooperative Governance and Traditional Affairs, 2011). Poor road conditions in the area (Chitakira et al., 2012b) limited accessibility especially in the middle zone with a predominantly mountainous terrain, posing farming challenges and making it difficult to access water for domestic uses. Due to high levels of poverty the MTA was designated an 'intervention area' i.e., one requiring poverty alleviation measures by the Umkhanyakude District Municipality (2013). Sustainable development interventions that economically empower the local farmers through diversifying income sources are necessary. Roads and built-up areas should be carefully planned and minimised because such developments may negatively impact biodiversity. Multifunctional landscapes can support sustainable off-farm income sources for smallholder farmers (Ecoagriculture Partners, 2012). There are opportunities for adventure or rural tourism identified in this TFCA community which, if developed, can improve self-reliance and alleviate poverty (Gumede \& Sutton, 2010; Mearns, 2012).

The questionnaire survey revealed that the communal farmers in the study community had a positive attitude towards natural resources conservation. Most probably, this attitude resulted from the farmers' interaction with environmental protection agents operating in the community (Chitakira et al., 2012a). Due to its location in a biodiversity hotspot the MTA attracted several local and international conservation agents who can offer important support for agriculture-biodiversity integration initiatives. The willingness of the local farmers to 
manage multifunctional landscapes presented opportunities for promoting TFCA objectives since these overlap with ecoagriculture goals (Chitakira et al., 2015).

This study showed that age and gender had no significant influence on the stakeholders' perception of landscape performance. It also revealed that the ratings by the local farmers (who were closely connected to the natural environment) did not significantly differ from those by external stakeholders (whose livelihoods did not depend directly on natural resources). This outcome confirms the validity of ratings by local communal farmers. It can be said that despite their low levels of formal education and training, communal farmers can assess the performance of local landscapes in a consistent way. This capability is most probably based on their knowledge of the area as indigenous people know their territory better than outsiders (Napolitano \& MacLennan, 2008).

Sustainable management of multifunctional landscapes requires consistent monitoring and taking measures to enhance performance (Shames et. al., 2017). The communal farmers had the potential to assess landscape performance and were willing to integrate agriculture and natural biodiversity but there was a need to develop systematic landscape performance monitoring skills. Development of such skills could be achieved through providing environmental education (in the local language) and farmer-training programmes. Raising the farmers' awareness of the benefits of new technologies and conservation measures would be important because farmers are unlikely to adopt a new technology if they do not perceive its immediate benefits (Demeke, 2003; FAO, 2012b; Tarawali et al., 2002).

This study provided information about the degree to which the landscape under focus conformed to the main goals of ecoagriculture. It revealed the dimensions of the landscape that require attention. The landscape performance displayed indicates the effectiveness of existing land uses and management practices in protecting biodiversity and supporting local 
livelihoods. This information can guide intervention measures, development planning and extension service provision. The results of the study can inform policy with regards to the allocation of resources across the landscape. For instance, low ratings for the production and livelihood dimensions point to a need for conservation initiatives that are compatible with farming and consistent with livelihood improvement. Increasing human population densities and demand for food and ecosystem services in the area (Jozini Local Municipality, 2013) posed a threat to the sustainability of existing unsystematic agriculture-biodiversity integration systems. Transforming the area into planned multifunctional landscapes with more coordinated management and monitoring systems could enhance its potential to provide food, ecosystem services and habitat for wild biodiversity. It is recommended that all stages of landscape management, from the initial feasibility studies through to implementation (decision-making and land use planning) be decentralised to empower local communal farmers. Participatory SWOT analysis and strategies to measure the effectiveness of the TFCAs could be adopted to support conservation objectives and strategic planning (Coad et al., 2015; Scolozzi et al., 2014). Conservation programmes could be designed from an ecoagriculture perspective to bring about synergies that benefit agricultural production and local livelihoods. In this regard, it is important to develop policies that promote agriculturebiodiversity integration in the TFCAs.

\section{Conclusion}

This study attempted to assess the performance of a landscape within a TFCA from the stakeholders' perspective. The participatory LPA in this study presented a forum for key stakeholders to reflect on a landscape that can simultaneously conserve biodiversity, deliver ecosystem services, sustain agricultural production and improve local livelihoods. The twenty questions used in this LPA are standard goals for a successful ecoagriculture landscape and 
can serve as a benchmark when planning, implementing and monitoring ecoagriculture projects. The use of indicators (production, livelihoods, biodiversity and institutions) in the assessment makes it possible to compare the performance of different landscapes. Further studies could analyse existing policies that relate to the utilisation and governance of natural resources in the TFCAs to show how these impact on agriculture-biodiversity integration at the landscape level.

\section{Acknowledgement}

The authors appreciate funding received from the International Foundation for Science, the

National Research Foundation (South Africa), CIRAD (France) and the University of Pretoria. We also thank Ezemvelo KwaZulu-Natal Wildlife and Wildlands Conservation Trust for logistical support. Thanks to the people of Mathenjwa for cooperation and to all who offered their support to this study.

\section{References}

Aref, F. (2011) Sense of Community and Participation for Tourism Development, Life Science Journal, 8(1), pp. 20-25.

Bastin, G. N., Ludwig, J. A., Eager, R. W., et al. (2002) Indicators of landscape function: comparing patchiness metrics using remotely-sensed data from rangelands, Ecological Indicators, 1(4), pp. 247-260.

Bellefontaine, R., Petit S., Pain-Orcet M., Deleporte P. H., \& Bertault J.G. (2002) Trees outside forests: towards better awareness (Rome: CIRAD, FAO). 
Benkhoua, N., Hafidi, M., Badri, W. et al. (2017) Management of the mycorrhizal soil infectivity with Crotalaria ochroleuca, an indigenous wild legume in the tropics: impacts on microbial functional diversity involved in phosphorus mobilization processes in a sahelian soil, Ecological Engineering, 101, pp. 130-136.

Brussaard, L., Caron, P., Campbell, B. et al. (2010) Reconciling biodiversity conservation and food security: scientific challenges for a new agriculture, Current Opinion in Environmental Sustainability, 2, pp. 34-42.

Buck, L. E. \& Scherr, S. J. (2011) Moving ecoagriculture into the mainstream, in: Worldwatch Institute, State of the World 2011: Innovations that Nourish the Planet (Washington DC.: Worldwatch Institute).

Buck, L. E., Milder, J. C., Gavin, T. A. \& Mukherjee, I. (2006) Understanding ecoagriculture: a framework for measuring landscape performance. Ecoagriculture Discussion Paper No. 2 (Washington, DC: Ecoagriculture Partners).

Butler, J. R. A., Wise, R. M., Skewes, T. D. et al. (2015) Integrating Top-Down and BottomUp Adaptation Planning to Build Adaptive Capacity: A Structured Learning Approach, Coastal Management, 43 (4), pp. 346-364.

Campbell, B. M., Sayer, J. A., Frost, P. et al. (2001) Assessing the performance of natural resource systems, Conservation Ecology, 5(2), pp. 27 [online].

Chitakira, M. (2013) Factors affecting ecoagriculture for integrated farming and biodiversity conservation in a transfrontier conservation area in Southern Africa, $\mathrm{PhD}$ Thesis (Pretoria: University of Pretoria). 
Chitakira, M., Torquebiau, E. \& Ferguson, W. (2012a) Unique combinations of stakeholders in a transfrontier conservation area promote biodiversity-agriculture integration, Journal of Sustainable Agriculture, 36, pp. 275-295.

Chitakira, M., Torquebiau, E. \& Ferguson, W. (2012b) Community visioning in a transfrontier conservation area in Southern Africa paves way towards landscapes combining agricultural production and biodiversity conservation, Journal of Environmental Planning and Management, 55(9), pp. 1228-1247.

Chitakira, M., Torquebiau, E., Ferguson, W. \& Mearns, K. (2015) Suggesting an interdisciplinary framework for the management of integrated production and conservation landscapes in a transfrontier conservation area of Southern Africa, in: N. Benkeblia (ed) Agroecology, ecosystems and sustainability, pp. 266-277 (Boca Raton: CRC Press).

Coad, L., Leverington, F., Knights, K. et al. (2015) Measuring impact of protected area management interventions: current and future use of the Global Database of Protected Area Management Effectiveness, Philosophical Transactions B. Biological Sciences, 370 (1681), [20140281]. DOI: 10.1098/rstb.2014.0281

Cooperative Governance and Traditional Affairs (2011) Umkhanyakude District Municipality profile (Pretoria: Department of Cooperative Governance and Traditional Affairs).

Demeke, A. B. (2003) Factors influencing the adoption of introduced soil conservation practices in north-western Ethiopia (Göttingen: Institute of Rural Development, University of Goettingen). 
Duffy, R. (2005) The potential and pitfalls of global environmental governance: the politics of transfrontier conservation areas in Southern Africa, Political Geography, 25, pp. 89-112.

Ecoagriculture Partners (2007) Guidelines for using the landscape performance scorecard, available at http://treadwell.cce.cornwell.edu/ecoag1a/ (accessed September 30, 2008).

Ecoagriculture Partners (2012) Landscapes for people, food and nature: the vision, the evidence, and next steps (Washington, DC: Landscapes for People, Food and Nature Initiative).

Evans, K., Bennett, E. M., \& Zurek, M. B. (2006) Field guide to the future: four ways for communities to think ahead (Nairobi: CIFOR, ASB, World Agroforestry Centre).

FAO (Food and Agricultural Organisation) (2012a) AGP - Biodiversity and ecosystem services, available at http://www.fao.org/agriculture/crops/corethemes/theme/biodiversity0/en/ (accessed August 23, 2016).

FAO (Food and Agriculture Organisation) (2012b) Economic aspects of conservation agriculture (Rome: Agriculture and Consumer Protection Department).

Farina, A. (2006) Principles and methods in landscape ecology: towards a science of the landscape (Dordrecht: Springer).

Freeman, R. E. (2010). Strategic management: a stakeholder approach (Boston: Pitman).

Government of South Africa (1998) National Veld and Forest Fire Act of 1998 (Pretoria: Department of Water Affairs and Forestry). 
Gruber, J. S. (2010) Key principles of community-based natural resource management: a synthesis and interpretation of identified effective approaches for managing the commons, Environmental Management, 45, pp. 52-66.

Gumede, B. R. \& Sutton, J. (2010) Feasibility study for the development of uSuthu Gorge adventure tourism facilities (Umhlanga, South Africa: Manje Isikhathi Trading Consultant Company).

Hörisch, J., Freeman, R. E. \& Schaltegger, S. (2014) Applying stakeholder theory in sustainability management: links, similarities, dissimilarities, and a conceptual framework, Organization \& Environment, 27(4), pp. 328-346.

Jackson, L. E., Pascual, U. \& Hodgkin, T. (2007) Utilizing and conserving agrobiodiversity in agricultural landscapes, Agriculture, Ecosystems \& Environment, 121, pp. 196210.

Jeffery, N. (2009) Stakeholder engagement: a road map to meaningful engagement, (Bedfordshire: Cranfield School of Management).

Jozini Local Municipality (2009) Integrated Development Plan (IDP) Review 2008/2009 (Jozini, South Africa: Jozini Local Municipality).

Jozini Local Municipality (2012) Integrated Development Plan (IDP) Review for 2011/12 FY (Jozini, South Africa: Jozini Local Municipality).

Jozini Local Municipality (2013) 2012/13 to 2016/17 Integrated Development Plan (IDP) (Jozini, South Africa: Jozini Local Municipality).

Jozini Local Municipality (2015) Integrated Development Plan (IDP): 2015/16 (Jozini, South Africa: Jozini Local Municipality). 
Kendle, A. D. \& Rose, J. E. (2000) The aliens have landed! What are the justifications for 'native only' policies in landscape plantings? Landscape and Urban Planning, 47, pp. 19-31.

Krováková, K., Semerádová, S., Mudrochová, M. and Skaloš, J. (2014) Landscape functions and their change - a review on methodological approaches, Ecological Engineering, 75, pp. 378-383.

Landscape Architecture Foundation (2017) The Landscape Performance Series, available at https://landscapeperformance.org/ (accessed February 26, 2017).

Lee, C. \& Coughlin, J. F. (2015), Perspective: older adults' adoption of technology: an integrated approach to identifying determinants and barriers, Journal of Product Innovation Management, 32, pp. 747-759.

Li, M., Dvorak, B., Luo, Y. \& Manskey, J. (2014) "Park Seventeen” residential roof garden: landscape performance and lessons learned, Landscape Research Record, 2, pp. 117131.

MaÔano, C., Ninot, G. \& Bilard, J. (2004) Age and Gender Effects on Global Self-Esteem and Physical Self-Perception in Adolescents, European Physical Education Review, $10(1)$, pp. $53-69$.

Mearns, K. F. (2013) Community-based tourism and peace parks benefit local communities through conservation in Southern Africa. Acta Academica, 44(2), pp. 70-87.

Mensah, S., Veldtman, R., Assogbadjo, A. E. et al. (2017) Ecosystem service importance and use vary with socio-environmental factors: A study from household-surveys in local communities of South Africa, Ecosystem Services, 23, pp. 1-8. 
Metcalfe, S. (2003) Impacts of transboundary protected areas on local communities in three Southern African initiatives. Paper prepared for the workshop on transboundary protected areas in the governance stream of the $5^{\text {th }}$ World Parks Congress, 12 to 13 September 2003, Durban, South Africa.

Moseley, M. J. (2003) Rural Development: principles and practice (London: SAGE Publications Ltd).

Mucina, L. \& Rutherford, M.C. (eds) (2006) The vegetation of South Africa, Lesotho and Swaziland. Strelitzia, 19 (Pretoria: South African National Biodiversity Institute).

Napolitano, D. \& MacLennan, G. J. (2008) Indigenous maps safeguard territories, available at http://environmentalresearchweb.org/cws/article/opinion/33319 (accessed August $23,2016)$.

Reed, M. S. (2008) Stakeholder participation for environmental management: a literature review, Biological Conservation, 14, pp. 2417-2431.

Reed, M.S., Kenter, J., Bonn, A. et al. (2013) Participatory scenario development for environmental management: a methodological framework illustrated with experience from the UK uplands, Journal of Environmental Management, 128, pp. 345-362.

SADC (Southern African Development Community) (2012) Transfrontier conservation areas, available at http://www.sadc.int/themes/natural-resources/transfrontier-conservationareas/ (accessed February 22, 2017).

Sayer, J., Campbell, B., Petheram, L. et al. (2007) Assessing environment and development in conservation areas, Biodiversity Conservation, 16, pp. 2677-2694. 
Scherr, S. J. \& McNeely, J. A. (2007) The challenge for ecoagriculture, in: S. J. Scherr \& J. A McNeely (eds) Farming with nature: the science and practice of ecoagriculture, pp. 1-16 (Washington, DC: Island Press).

Scherr, S. J., Buck, L. E., \& Majanen, T. et al. (2011) Scaling-up landscape investment approaches in Africa: where do private market incentives converge with landscape restoration goals? Background paper for the Investment Forum on mobilizing investment in trees and landscape restoration (Washington DC: Ecoagriculture Partners and Program on Forests).

Scherr, S. J., Buck, L., Willemen, L. \& Milder, J. C. (2014) Ecoagriculture: Integrated landscape management for people, food and nature, Encyclopedia of Agriculture and Food Systems, 3, pp. 1-99.

Scolozzi, R., Schirpke, U., Morri, E., D'Amato, D. \& Santolini, R. (2014) Ecosystem services-based SWOT analysis of protected areas for conservation strategies, Journal of Environmental Management, 146, pp. 543-551.

Shames, S., Heiner, K. \& Scherr, S. (2017) Public Policy Guidelines for Integrated Landscape Management (Washington DC: Ecoagriculture Partners).

Shames, S. \& Scherr, S. J. (2009) Agriculture and the convention on biological diversity: guidelines for applying the ecosystem approach, Ecoagriculture Discussion Paper No. 4 (Washington DC: Ecoagriculture Partners).

Sotho, B., Munthali, S. M. \& Breen, C. (2001) Perceptions of the forestry and wildlife policy by the local communities living in the Maputo Elephant Reserve, Mozambique, Biodiversity and Conservation, 10, pp. 1723-1738. 
Stockdale, A. \& Barker, A. (2009) Sustainability and the multifunctional landscape: an assessment of approaches to planning and management in the Cairngorms National Park, Land Use Policy, 26(2), pp. 479-492.

Taner, R., Modi, S. K. \& Stewart, D. M. (2014) A 'Texas three-step' landscape performance research: learning from Buffalo Bayou Promenade, Klyde Warren Park, and UT Dallas Campus Plan Ozdil, Landscape Research Record, 2, pp. 148-156.

Tarawali, G., Douthwaite, B., de Haan, N. C. \& Tarawali, S. A. (2002) Farmers as codevelopers and adopters of green-manure cover crops in West and Central Africa, in: C. B. Barrett, F. Place \& A. A. Aboud (eds) Natural resources management in African agriculture: understanding and improving current practices, pp. 65-76 (Wallingford: CABI Publishing).

Torquebiau, E., Dosso, M., Nakaggwa, F. \& Philippon, O. (2012) Biodiversity conservation through farming: a landscape assessment in KwaZulu-Natal, South Africa, Journal of Sustainable Agriculture, 36(3), pp. 296-318.

Umkhanyakude District Municipality (2013) Integrated Development Plan Review, 3rd Generation: 2013/2014 (Mkhuze, South Africa: Umkhanyakude District Municipality).

Vallance, S. (2011) Community, resilience and recovery: building or burning bridges? Lincoln Planning Review, 3(1), pp. 4-8.

Van Wyk, A. E. \& Smith, G. F. (2001) Regions of floristic endemism in Southern Africa: a review with emphasis on succulents (Pretoria: Umdaus Press).

Voinov, A., Kolagani, N., McCall, M. K. et al. (2016) Modelling with stakeholders - next generation, Environmental Modelling \& Software, 77, pp. 196-220. 
Willemen, L. (2010) Mapping and modelling multifunctional landscapes, $\mathrm{PhD}$ Thesis (Wageningen: Wageningen University).

Willemen, L., Kozar, R., Desalegn, A. \& Buck, L.E. (2014) Spatial planning and monitoring of landscape interventions: maps to link people with their landscapes: a user's guide (Washington, DC: EcoAgriculture Partners).

Wood, D. \& Lenné, J. M. (2005) 'Received wisdom' in agricultural land use policy: 10 years on from Rio, Land Use Policy, 22, pp. 75-93.

Xu, J., Wu, C. \& Ma, X. (2014) Landscape performance assessment of urban wetland park planning and design: case study of Wuzhou Wetland Park in China, Landscape Research Record, 2, pp. 106-116.

Yang, B., Blackmore, P. \& Binder, C. (2013) Capitol Valley Ranch landscape performance benefits assessment. Landscape Architecture and Environmental Planning Faculty publications. Paper 144, available at http://digitalcommons.usu.edu/laep facpub/144 (accessed January 19, 2017). 